\title{
De-constructing Terracotta Female Figurines: a Chalcolithic Case-study
}

\author{
Andrea Pizzeghello ${ }^{a}$, Massimo Vidale ${ }^{a^{*}}$, Giuseppe Salemi ${ }^{a}$, Vincenzo Tinè ${ }^{b}$, Sergio Di Pilato ${ }^{c}$ \\ ${ }^{a}$ Department of Cultural Heritage: Archaeology, History of Art, Music and Cinema, University of Padua, Italy \\ ${ }^{b}$ Archaeological Superintendency of the Veneto Region, Italy \\ cPantamedica, Fidene, Italy
}

\section{ARTICLE INFO}

\section{Article history:}

Recieved: $8^{\text {th }}$ August 2014

Accepted: $29^{\text {th }}$ July 2015

\section{Keywords:}

prehistoric female figurines

Hacilar I

CT scanning

Chalcolithic modelling techniques

\begin{abstract}
$A B S T R A C T$
We report the results of detailed imaging studies of the inner structure of a terracotta female figurine dated to the $6^{\text {th }}$ millennium $\mathrm{BC}$, most probably from the Lakes region of Turkey, now kept at the National Museum of Oriental Art "Giuseppe Tucci", Rome. The figurine was investigated with advanced CT scanning, recording 966 transversal sections. Each section was stratigraphically interpreted and digitized, reconstructing in three dimensions the form and mode of application of each lump or slab under the potter's fingers. A review of the available information on the techniques of construction of prehistoric terracotta figurines in Eurasia reveals at least two diverging technical templates, here named core and dual forming processes. The structure of the investigated figurine and its operational sequence reveals a version of the dual technical template, confirming the presence and influence, at a cognitive level, of organic analogies and a possible map of the female body in the modelling process.
\end{abstract}

\section{Introduction}

The aim of this paper is to confirm that non-destructive, advanced CT scanning techniques can be applied to prehistoric terracotta figurines, revealing important details of their inner structure resulting from clay manipulation and forming. Furthermore, we show that such an approach, supported by a more traditional micro-stratigraphical interpretation and by archaeological know-how, may grant a complete three-dimensional rendering of their growing structure. From this we can retrace, step by step (or lump by lump), the sequence of fine, perhaps almost unconscious decisions and corrections (Van der Leew 1993) put in play while generating the terracotta images.

Why are terracotta female statuettes and their building processes important? Figural art was a crucial component of prehistoric social structures, and the female life cycle was at the core of the survival and reproduction of the household.

*Corresponding author. E-mail: mass.vidale@gmail.com
One can hardly doubt of the artifacts' prominent symbolic values for representing female bodies; and their fashioning sequences may show - by dynamic, three-dimensional maps - some important cognitive implications. Admittedly, to identify the agency of the artists, and to decide on such a line of evidence whether the figurines referred to supernatural, or rather to gender, sexuality and reproduction issues will probably remain beyond our power of definition. However, the old and current studies reviewed in the following section support the idea that by re-enacting the potter's creative process and by evaluating at the same time the general archaeological context, we can better understand the active roles played by female figurines in past social systems.

\section{A short review of previous research}

For a long time, clay and terracotta Neolithic/Chalcolithic female statuettes have been generally and generically interpreted as images of goddesses, worshippers or supplicant women (Mellaart 1967; 1975). Since the famous discoveries 
at Hacilar (Mellaart 1970, 170), they have also been linked to the popular concept of an archaic Mother Goddess and to conjectural fertility cults by pristine matriarchal societies (Gimbutas 1991, contra Ucko 1968; 1996; Meskell 1995; 1998; Tringham, Conkey 1998; Clark 2007b).

In contrast with generalistic and ideological interpretations, inspired by the paradigm of a presumed (and never ascertained) similarity of these figurines across no less than three or four millennia, new critical approaches have focused on their active roles in the dialectic construction of personhood and social and gender identities through stereotypical body characterizations of the human body.

For example, in Chalcolithic Cyprus a well-preserved ritual hoard suggested that figurines "...were clutched in the hand, probably during childbirth, while the ceramic figurines served a didactic purpose, perhaps as part of puberty rites" (Bolger 1996, 368). The idea is interesting, but impossible to verify. Voigt $(2007,165)$ states that Hacilar female images might reflect the life cycle of women and their changing social roles through time, from young girls to mature individuals. A similar template was recognized in the Neolithic statuettes' corpus of Crete and the Aegean (Mina 2008, 123; see also final comments in Nanoglou 2010, 222), while at Chatalhöyük, where "...many of the human figurines are suggestive of aging bodies rather than young and reproductive types" (Nakamura, Meskell 2009, 219), bodily excess and obesity might hint to resource abundance, and metaphorically to mature age, accumulated experience and knowledge, personal success and social respect. In short, female figurines are now reconsidered for studying "women" and their active roles in prehistoric societies (Knapp, Meskell 1997; Lesure 2010), rather than "the woman," as a more qualified focus of research.

Besides reference to the life cycle of females, some prehistoric figurines were interpreted at the same time as feminine as well as phallomorphs (Lamberg-Karlovsky, Meadow 1970; Bar-Yosef 1980; Özdogan 2003; Clark 2007a, 19; Nakamura, Meskell 2009, 212, 222-223). These speculations emphasize one of the many aspects of gender ambiguity that can be empirically perceived in this intriguing class of artefacts (Kuijt, Chesson 2005; see also Nanoglou 2010).

Among others, Lesure $(2002,587)$ has called for a "...greater level of sophistication to figurine analysis by emphasizing diversity among the images and attempting to elucidate the meanings and uses of figurines in particular times and places." Meaning, however, will remain elusive, as it "...continually arises from acts of engagement and articulation. This relationality is precisely what constitutes the figurine as a process rather than simply a thing... The figurine does not only sustain, but demands multiple viewpoints...it anchors a dynamic network of encounters with and between individuals and coproduces various and often concomitant perceptions, experiences, and knowledges" (Nakamura, Meskell 2009, 210; see also for discussion Clark 2007a, 15).

If Nakamura's and Meskell's figurines demand multiple viewpoints, we need to investigate outside as well as inside figurines. Spatial and relational contexts outside the figurines have appeared crucial since Ucko (1968). Many authors, in fact, have stressed the need of moving, beyond iconography and the traditional ways of evaluating symbols, to a holistic hypothesis of figurines in their dynamic, relational framework with the rest of the involved archaeological record. This approach focuses on terracotta female figurines as "social ceramics" (Starnini 2014). While in this light the semeiotics of archaeological meaning becomes a crucial issue, particularly when dealing with old excavations (Louhivouri 2010), a growing concern for contextual evaluation has introduced new spheres of information. These include not only the material terms of site formation processes (e.g. Abay 2003; Perlés 2004, 255-272; Clark 2009, 253-254), but also correlations with pervasive cultural templates (Langin-Hooper 2014). Among these studies, particularly inspiring are those exploring the links of female figurines with Neolithic mortuary practices (Kujit, Chesson 2005, 175-176; Nakamura, Meskell 2009).

In this paper, we rather propose an in-depth, within the figurine investigation, following Nakamura and Meskell's paradigm of figurines as processes. The artefact itself is viewed in a composite and stratified archaeological context, whose interpretation proceeds (at least in part) independently from the rest of the site.

\section{Female figurines as processes: use and construction}

Investigating within the figurine means to observe, in greater detail and from new points of view, its materiality. In some rare cases, material modifications of the ceramic bodies provide a direct key to the figurines' active roles and to social interaction in ancient societies. In northern Baluchistan, for example, female figurines dating from the $7^{\text {th }}$ millennium $\mathrm{BC}$, associated with snakes (painted or modelled), may have had magic functions, as some, while in a plastic state, were pierced with multiple holes (Jarrige 2007-2008). At Malta, a Neolithic clay figure of a pregnant woman contained multiple insertions of shell and bone flakes in particular anatomical parts, and another statuette of a female in the same conditions was found with possible images of fetuses in various stages of development. Both images are interpreted as items of sorcery (Rich 2008). Evident wear patterns on the surface seems to indicate intensive handling (Nishiaki 2007, 121; Bolger 1996, 368). Other forms of manipulation are embedded in the structure of composite figurines. In Neolithic Chatalhöyük, headless figurines with dowel holes for removable heads, including skeletal ones, and a higher number of heads made for attachment were linked to the peculiar post-burial treatment of human remains and to the ritual manipulation of skulls in Neolithic times (Meskell 2008).

This shows how another important processual aspect of figurines, like of many other ceramic artefacts, lies at the root of their "life" cycle. i.e., manufacturing technology. There is little doubt that the cultural roles of anthropomorphic 
figurines, like the rest of material culture, should be described in terms of behavioural chains, activities, material interactions, technical choices, performance and adaptation (Lemonnier 1993; Miller 1998; Skibo, Schiffer 2008). In fact “...stages of manufacture (chaîne opératoire) are another locus for symbolic discourse and negotiation of gender identities... Symbolic meaning generated by figurines may also have been expressed through prohibition on the involvement of certain gender and age categories in their production, the pyrotechnical aspects of manufacture and symbolic associations with fire, 'hot' and 'cold' activities and things, and through the parallel treatment of the clay and physical body as in the application of decoration." (Mina 2008, 116-117; see also Dobres 2009, 2000; Dobres, Robb 2000). Nonetheless, such important research perspectives originally belong to the sphere of systemic contexts and only indirectly to the heuristic and harder realm of paleotechnological indicators.

So far, in fact, with few exceptions, the manufacturing technology of Neolithic and Chalcolithic clay female figurines has received marginal attention. For example, in Neolithic Greece their manufacturing was described as follows: "...the different parts of the body were made separately, often around a clay or stone pellet, and pegged or stuck together without much care. Consequently, they frequently broke apart. If they were initially conceived as short-lived artefacts, the high frequency of 'split-legs', for instance, need not be invested with special social significance" (Perlés 2004, 263).

While the described conditions might fit this and other particular cases, a preliminary review of the published information hints at a more complex attention to detail. Here, we discuss two different technical approaches so far recognized in the literature on the prehistoric clay female figurines of Eurasia. These two approaches are respectively labeled core and dual forming techniques.

\section{Constructing figurines: core forming}

We recognize two diverging technical and cognitive approaches in the construction of clay and terracotta prehistoric figurines, respectively named core forming and dual forming techniques. In core forming, the sequence started from an inner core on which other plastic elements (legs, arms, head) were gradually added. In this process the basic cognitive model is radial symmetry, the limbs being applied as radial appendages to the solid core. The Neolithic Greek figurines mentioned by Perlés were evidently made in this way.

Similarly, in a Neolithic female figurine from Tell Seker al-Aheimar, Northeast Syria, about 7000 cal. BC, “...The broken surface shows that the body was constructed with different lumps of clay, using a flask-shaped lump as the core. A few layers of mud plaster are also visible" (Nishiaki 2007, 121). This description hints at a concentric slabconstruction process starting from a simply formed single core. In another Neolithic fragmentary clay figurine found in Poland, the stretched legs are described as made of a single lump (Debiec, Dzbynski 2006). A variant of this coreconcentric building technique was recently identified in a $6^{\text {th }}$ millennium fragmentary female image of the early Neolithic Körös culture, Hungary (Kreiter et al. 2014). Some have argued that core forming techniques in Neolithic and early Chalcolithic Eurasia might have had important symbolic implications in terms of creation, as the innermost lump served as a corpus to which the fleshy skeletal parts were gradually added (Hourmouziadis 1973, 40; Nanoglou 2008, 318; Clark 2009, 240). They may have even been shaped as a hidden spiral-like organ - perhaps a womb, recently interpreted as a symbol of a possible "...transubstantiation of divinities" (Pavel et al. 2013, 332).

In some cases, the construction technique of the figurines, in particular those starting from a core, was related to postfruition dynamics and to a possible deliberate fragmentation. In some Vinča Culture sites in Serbia, such as Opovo and Selevac (Tringham, Conkey 1998), but recently also in Italy in the early Neolithic site of Favella (Tiné 2009), broken statuettes were found in pit-structures fill along with fired daub fragments, the only evidence of vanished dwelling structures. Both at Opovo and Favella each pit contained a fragment of a statuette, with a systematic redundancy ascribed to specific ritual performances linked to house defunctionalization and burning (Tringham 2005). It has been argued that fragmentation was determined to accompany the fate of housing structures, with a deliberate process, welldocumented in the Balkans and as early as in the Korös culture in Hungary, where statuettes were built in parts to be intentionally dismembered (Makkay 1998). In other settings this model was related to a specific process of fragmentation and burial of worship objects (Chapman, Gaydarska 2007). Thus, by applying separate parts to the core, people would have forecasted an easier (and anatomically correct) fragmentation and subsequent intra-site dispersal.

\section{Dual forming techniques}

For dual forming, in contrast, the torso and more generally the body is made by joining two elongated slabs or lumps along a central axis of symmetry, while the rest is applied in bi-lateral or concentric patterns. O. Muscarella (1971: Fig. 5) observed exactly this process on a fractured Hacilar female figurine that turned out authentic when tested with thermoluminescence. Its identification, however, has a longer and geographically widespread history.

In 1959, Bass had described this technique in some Neolithic fragmentary figurines found at Thespiai, Greece, based upon a careful scrutiny of the fracture surfaces. The best preserved specimen was "...formed of long, oval pellets of clay, pressed together and covered with the thick coating of clay which forms the surface. Two pellets, side by side, made up the chest, and four were used in the stomach. Legs, buttocks, arm and head were made of separate cores and attached before the final coating. The separate lumps of clay 


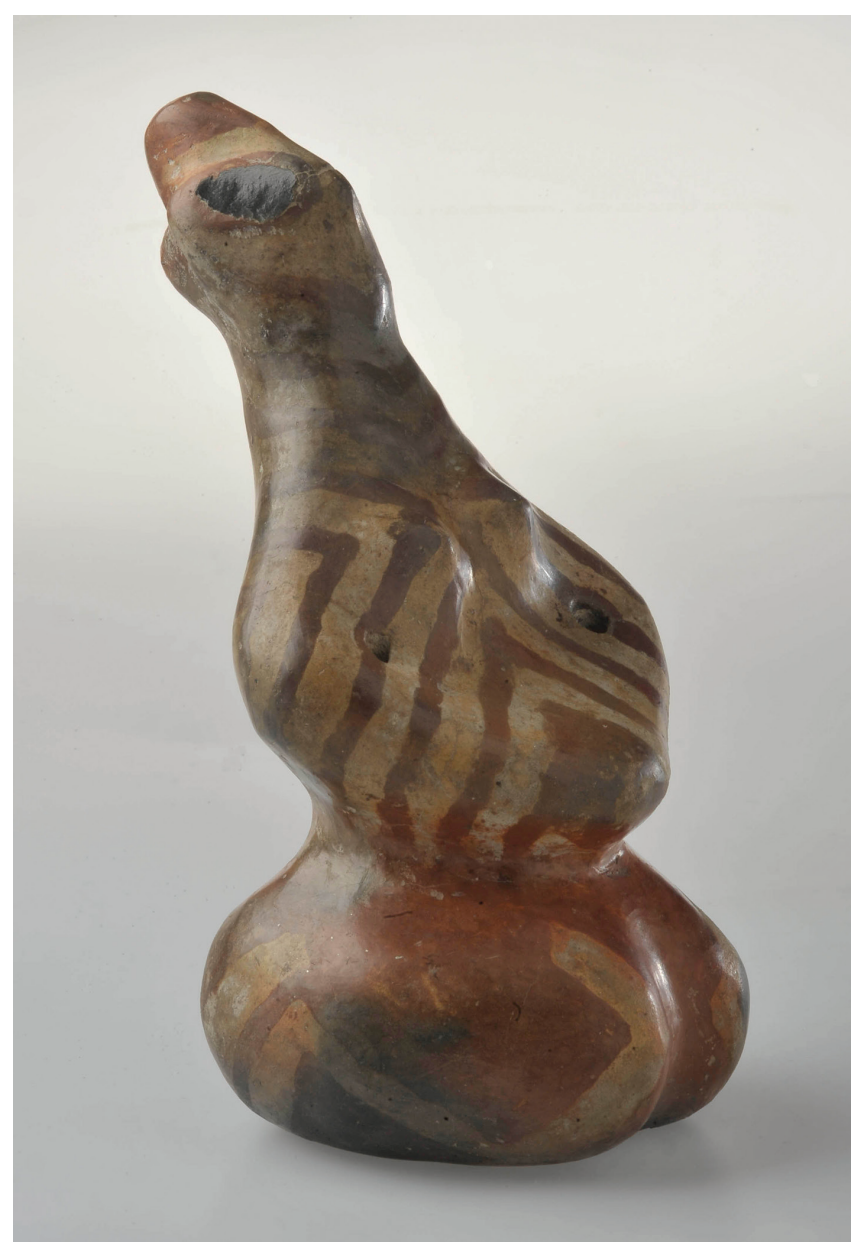

Figure 1. The terracotta figurine National Museum of Oriental Art (MNAO), Rome (inv. 21392/31729), presumably from the Burdur Lakes region, Turkey, in right lateral view. Photo Edoardo Loliva (ISCR, Rome).

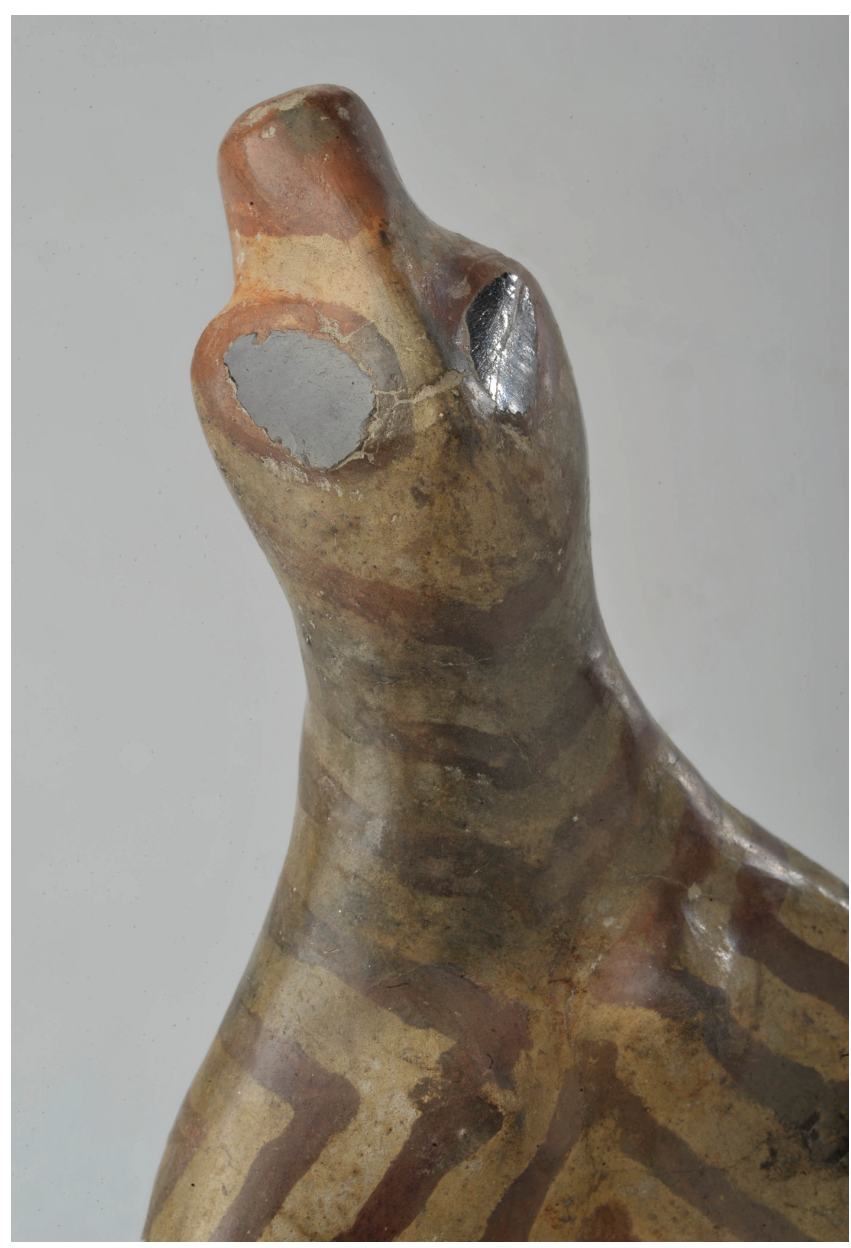

Figure 2. Detail (front view) of the head of the terracotta figurine MNAO 21392/31729, showing the eyes made with inserted obsidian bladelets (ventral side). Photo Edoardo Loliva (ISCR, Rome). did not coalesce, accounting for the break down the middle of the torso, which leaves half the pellets and gives a clear cross section of the interior anatomy." (Bass 1959, 344, Pl. $74,1)$.

The fractures of an early Neolithic terracotta figurine from Austria $\left(5650-5100 \mathrm{BC},{ }^{14} \mathrm{C}\right.$ cal.) similarly revealed that the upper torso was made of two vertically joined slabs, perhaps applied upon a larger cylindrical lower body (Sauter et al. 2002, Figures 1 and 2). A scout view of a CT scanning of a late Neolithic female figurine from Shaar Hagolan (Israel) reveals a torso made precisely in the same way (Applbaum, Applbaum 2005, 240), as do the surface cracks on the late Neolithic clay figurines of Ulucak Höyük (ca. 6000-5700 cal. BC) (Abay 2003, Figure 7, bottom left). The same construction technique was recently identified beyond any possible doubt through the CAT scan of a female figurine of the Chalcolithic Cucuteni culture of Romania (Pavel et al. 2013).

The construction of the Bronze age female figurines of the Indus civilization was judged to be “... very different from that of some ancient Near Eastern figurines in which a head, arms, and legs were attached to a violin-shaped torso or 'core'... the faces were pinched out from the two joined vertical rolls of clay rather than being attached and the legs are continuations of two rolls of clay rather than separate pieces applied to a 'core'..." (Clark 2009, 246). The same author proposed that such a forming technique might symbolically represent creation by the integration of two opposite halves (see also Dales 1991). On the other hand, the same dual construction technique has been independently observed in radiography in an animal figurine from the $3^{\text {rd }}$ millennium site of Shahr-i Sokhta at the Iranian portion of the Sistan basin (Bollati et al. 2009).

Thus, in Eurasian protohistory dual techniques may be as old as core-forming ones, and there are no simple geographic boundaries describing their relative spread. Cultural and symbolic implications of the different cognitive approaches are an open line of inquiry. It is worth noting that dual building techniques might be linked to modes of fragmentation enhancing "non-potential breakages" (especially at the middle of the trunk) observed in some Balkan Neolithic contexts (Chapman 2000). 


\section{The object and methodology of the study}

We decided to investigate the manufacturing process of a Chalcolithic terracotta figurine through the CT scanning of its inner structure (Hughes 2011) following an ad hoc pipeline. We searched for evidence of one or the other technical process and for any other possible inner structure that might have revealed specific templates. The solid figurine we analyzed $(16 \times 7 \times 6,5 \mathrm{~cm})$ is a recent acquisition (2007) of the National Museum of Oriental Art, Rome (Figures 1 and 2, inv. 21392/31729). Although its precise origin is unknown, an almost identical figurine, kept at the Burdur Muzesi, Turkey (Inv. Nr. E4999, Badishen Landesmuseum Karlsruhe 2007: 363, Figure 383), places our specimen in the Lakes region and dates it around 5500-5250 BC. The same approximate date is confirmed by two vessels that accompanied the figurine to the Rome Museum (Bollati et al. 2012) and by a third figurine of the same type, now at Florence (Guidotti et al. 2007, 210). From a formal viewpoint, the figurine matches Mellaart's type B3 (1970: P1. CLXXB, Figure 245, 1 and 3), or "kneeling female figure." See critical remarks and analytical data on Hacilar female images in Muscarella (1971).

The figurine leans back at an angle of $70^{\circ}$. The bent legs appear as two egg-shaped, thick elements and the buttocks are well-defined. At the sides of the torso, the arms are represented by two oblique, short cylindrical holes. A central projection stands for the hands. The breasts are small, and the neck and head are not distinguished. When observed from the side, the round bent legs and thinner, elongated body give to the figurine an apparent phallic characterization, and thus might fall under the categories of intriguing gender ambiguity previously remarked by several authors, quoted above. We specifically wondered whether the inner structure of the image might have supported or weakened the hypothetical analogy with a phallus. On the face (Figure 2), two obsidian bladelets were inserted in the final stages of polishing, the flat ventral side in sight.

The outer surface is smooth, highly polished and covered with broad, angular motifs traced with a thick red pigment, apparently rich in iron oxides. The figurine is painted with a complex symmetrical motif - concentric angles converging on the chest, while legs are filled equally symmetrically with solid patterns in which S-shaped, angular designs appear in the negative. A solid lozenge appears at the height of the joint hands. In short, the painted figuration follows a bilateral symmetry, but at the same time the lower and upper parts of the body are painted following opposite templates. On the back are visible rows of angular designs and an empty losange is at the base of the spine, ideally opposed to the solid lozenge on the hands in front: again, painted decoration precisely follows a central axis of symmetry and a complex play of graphic oppositions. No evidence of surface wear or substantial manipulation was detected.

The CT scanning was made by one of the authors (SDP) at the Hospital Regina Margherita, Rome, with a General Electric Bright speeds 16 Turbo Solaris, an advanced

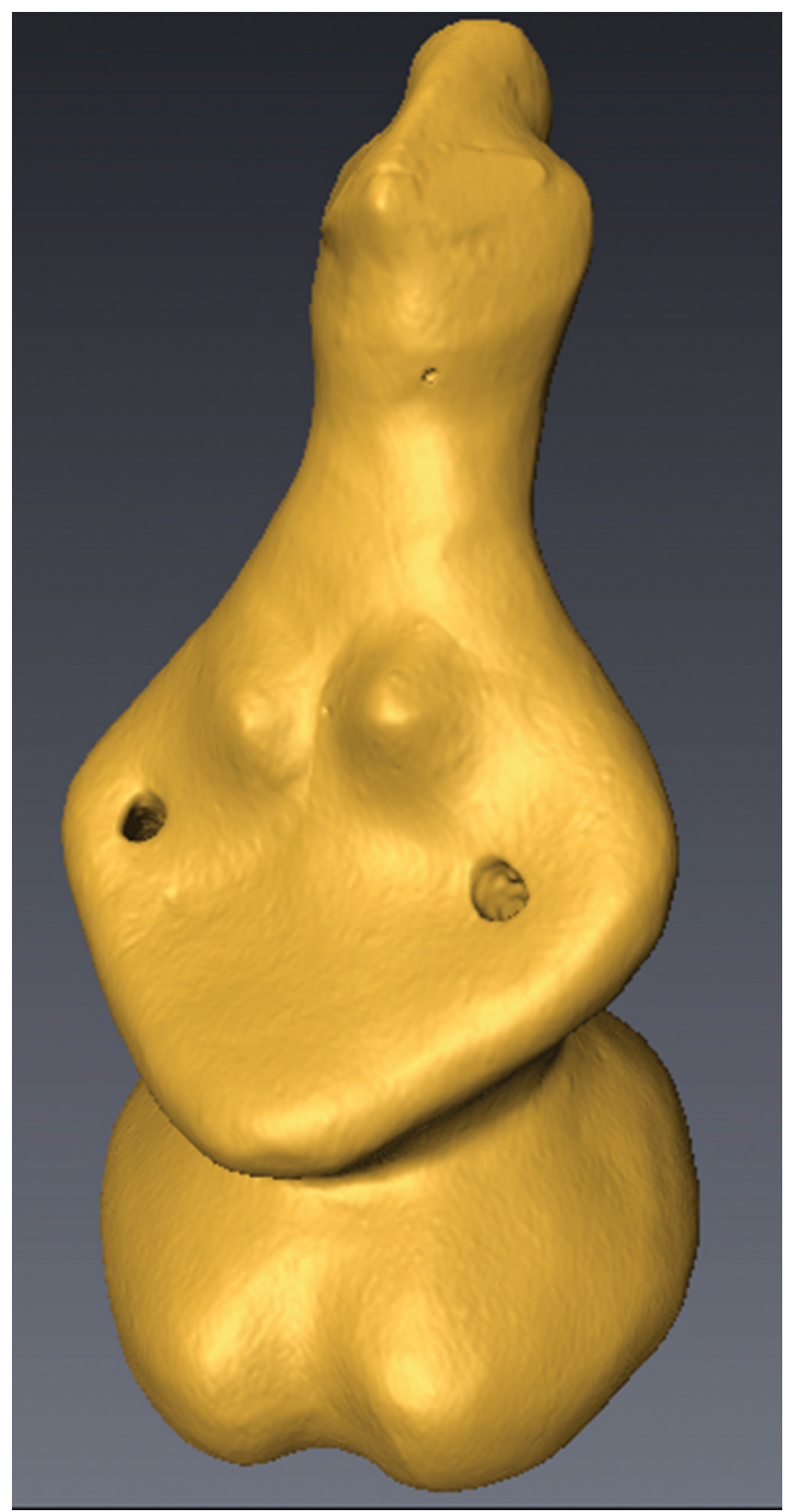

Figure 3. Volumetric rendering of the terracotta figurine by means of CT scanning.

facility that created for each section 16 additional microlayers. Later, DICOM data were obtained as a unique file and treated with software AVIZO7, reading the 966 visible layers, corresponding to 531 sections on the XY axis, 212 for the $\mathrm{XZ}$ axis, and 223 for the $\mathrm{YZ}$ one.

Figure 3 shows the outer volume of the image as reconstructed. The inner structure was interpreted and reconstructed by emphasizing, section after section, the phase discontinuities among the inner lumps and slabs. When such discontinuities or interfaces became less distinct, we applied a "glow.col" enhancing filter, and through a "segmentation editor" we operated on the three-dimensional volumes of each inner lump or slab (hereafter Technical Episode or 

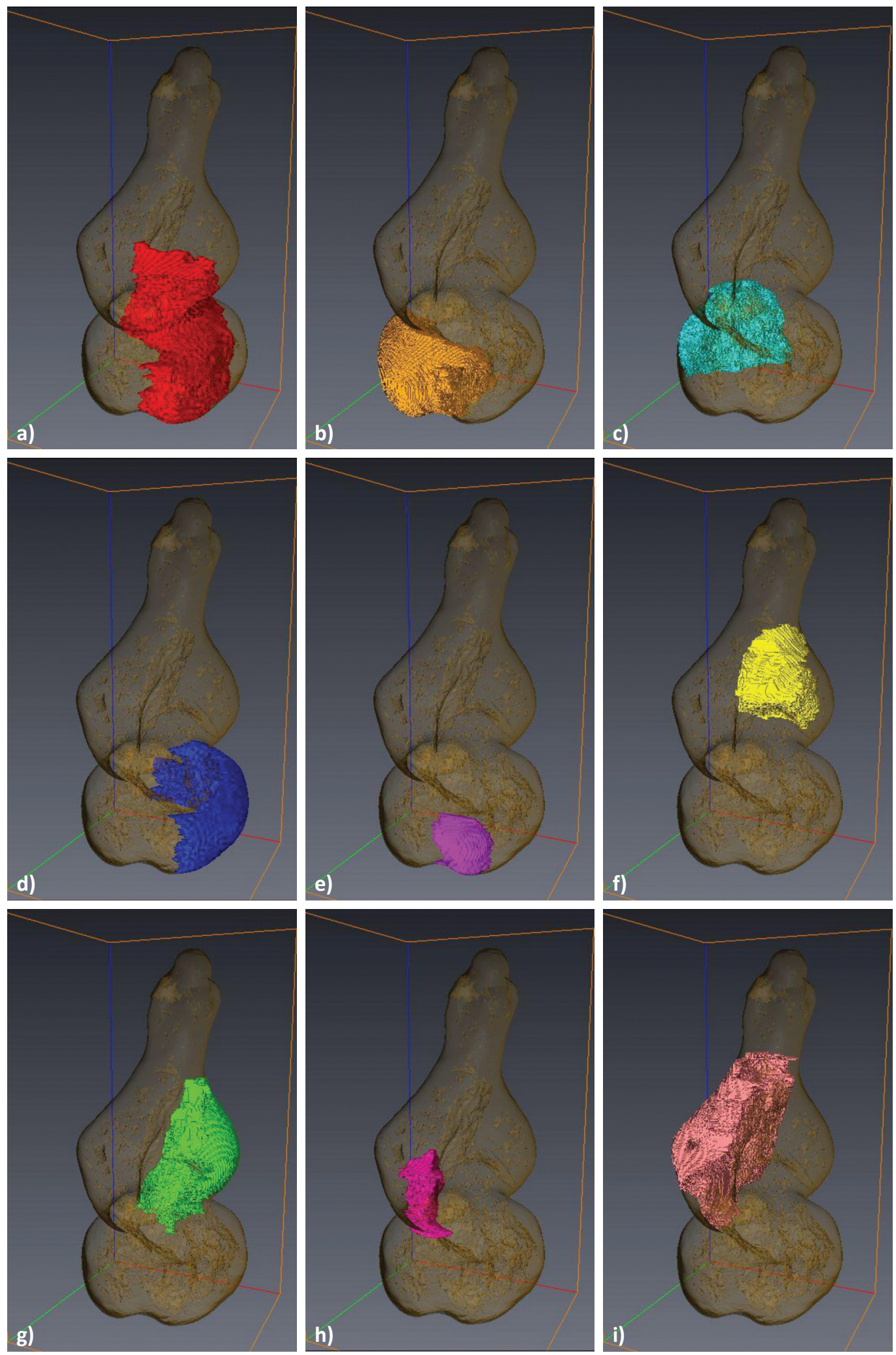

Figures 4. Form and location of the 19 individual TEs discovered by means of the CT scanning and following micro-stratigraphic interpretation.

TE). In order to measure each inner TE, we made a cage of six orthogonal planes ("ortho slices") defining a virtual tetrahedron, where couples of parallel slices are placed at the extremities of the TEs.
These eventually were represented as individual three-dimensional elements by different colors for better visualization (Figure 4a-r). They were treated as the main indicators of a plastic addition process, from 

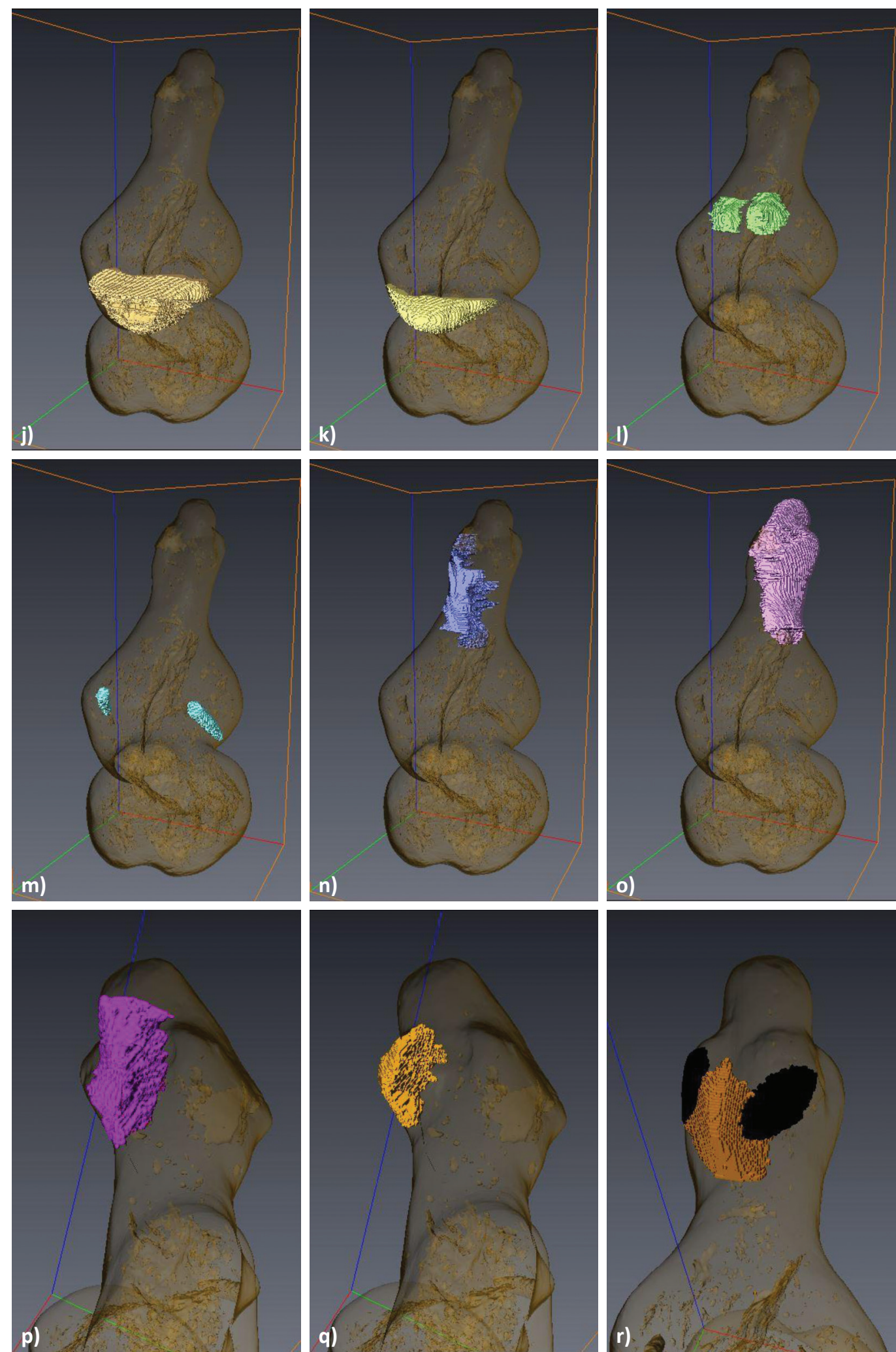

Figures 4. Form and location of the 19 individual TEs discovered by means of the CT scanning and following micro-stratigraphic interpretation. (Continuation).

the lower limbs to abdomen, torso, head and the applied obsidian inserts, resulting in a final, high resolution rendering of the composite volume of the figurine (Figure 5).
Our first goal was a detailed reconstruction of the operational sequence of the clay modelling in terms of subsequent TEs, formalized as a stratigraphical flow chart. Secondly, we tried to define each TE in terms of geometrical- 


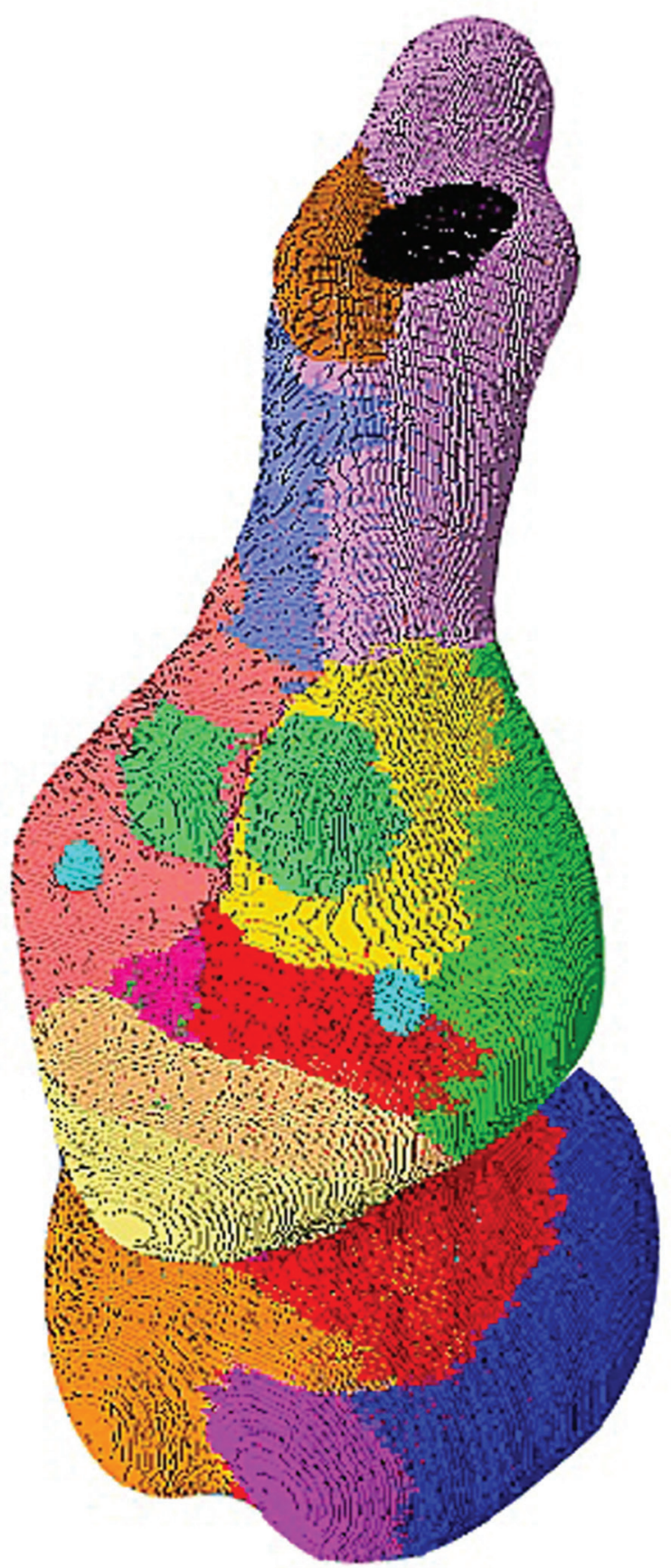

Figure 5. General interpretation of the inner structure of the figurine, reconstructed by means (after interpretion) of the evidence of CT scanning and following micro-stratigrafic interpretation of 966 sections. Each colored part corresponds to a specific added lump or slab (Technical Episodes or TEs, see Figure 4). The construction sequence is detailed in the following Figure 6 and in Table 1 (see text).

topological features (after van der Leeuw 1994, 136-137) and of the partonomy of the sub-sequences of TEs by which the figurine was made, possibly defined by temporary interruptions. This three-level abstraction allowed us to transform a set of pure forms into a hypothesis of technical and cognitive strategy. Having reconstructed in 3D the shape of each lump or slab applied to form the clay sculpture, and thus the sequence of modelling, we then compared this latter to the technical approaches mentioned above. We then searched in the figurine's hidden structure any possible analogy with the human body and/or its parts. Moreover, we wanted to ascertain whether the inner structure itself had any resemblance to a penis or not.

\section{De-construction}

The CT sections show, as main phase discontinuities, several light-coloured inclusions (large-sized silicate grains, mostly with angular contours) and linear, curved interfaces, considered the main indicators of the slab/lump construction sequence. The sections show that the surface of the figurine is formed by an outer peel of fine clay a few millimetres thick. In the images and in the reconstructions, this fine "skin", evidently applied in the final finishing stage, is not emphasized.

Table 1 attempts to define analytically the sequence of TEs we identified, their partonomical pertinence (i.e. their belonging to the base, torso or head, three fundamental moments in the construction of the figurine) and their geometrical-topological features (pellet, lump or slab, anatomical reference; we identified the hand-forming techniques that, on the basis of actualistic considerations, were presumably used in each TE). Table 1 summarizes the 3D map and stratigraphic flow chart of Figure 6.

These analytical results (Figures 5, 6) show that the beginning of the sequence was the inner core of the left leg, from which rose a vertical slab, meant to become part of the figurine's back (TE1). The forming sequence continued by joining to a shapeless inner piece (or support) a series of hemispherical or cone-shaped forms (TE2-TE5) that gradually reproduced two paired bent legs and buttocks. TE5 was clearly applied on the right as a "knee" for matching symmetrically the shape of the left leg. This sequence, in spite of its formal discontinuity, retained a basic axial symmetry, at least in front and in the final vision.

The vertical extremity of TE1 was planned for better fixing the base to the torso. In the middle body, TE6 and TE7, two slabs joined vertically on the figurine's axis, confirm the evidently dual organization of the slab contruction process. This is further enhanced by the symmetry of TEs 9 and 10 (left and right shoulders), of the applied breasts (TE12), of the two holes at the elbows (TE13) and of two other paired elongated strips that form the neck and the head (TEs 14 and 15); as obviously do the obsidian eyes (TE19). The protuberance of the clutched hands (TE11), the nose (TE18) and the probable headdress on the nape (TEs 16 and 17) are on the central axis of symmetry. If the legs and buttocks were mostly made of hemispherical parts, the torso area was made with flatter slabs and sub-triangular applications (TEs 9, 10, 11). Ultimately such a composite, bi-lateral inner structure points to a map of the female body and rejects the apparent similarity to a male organ, that might have been more simply expressed with a cylindrical shaft and round appendages for the testicles. 
Table 1. Partonomy, geometric-topological features and technical performance of the modelling sequence of the Rome figurine (terms after van der Leew 1994) as defined by means of CT and ensuing digital processing. See also Figure 5.

\begin{tabular}{llll}
\hline TEs & Partonomy & Geometrical-topological features, metadata & Modelling (actualistic hypothesis) \\
\hline TE1 & base, legs, abdomen & vertical elongated lump, core of left leg & $\begin{array}{l}\text { palm-squeezing } \\
\text { pinching or palm-forming, joining, } \\
\text { rounding } \\
\text { pinching or palm-forming, joining, } \\
\text { reunding }\end{array}$ \\
base, legs, abdomen & hemisphere, front of right leg & palm-forming, joining \\
TE3 & base, legs, abdomen & hemisphere, right buttock & pinching or palm-forming, joining, \\
TE4 & base, legs, abdomen & egg-shaped lump, left leg and buttock & rounding \\
TE5 & base, legs, abdomen & cone/hemisphere, right knee & pinching, joining, forming \\
TE6 & middle body, torso & elongated slab, up to left side and left arm & pinching, flattening, joining, forming \\
TE7 & middle body, torso & flat slab, right side of the back and right arm & pellet forming, infilling \\
TE8 & middle body, torso & filling of a triangular gap in the belly & pinching, joining, forming \\
TE9 & middle body, torso & flat triangle, right shoulder, elbow and forearm & pinching, joining, forming \\
TE10 & middle body, torso & flat triangle, left shoulder and left upper chest & pinching, flattening, joining, forming \\
TE11 & middle body, torso & horizontal flat triangle, hands clutched in front & pinching, joining \\
TE12 & middle body, torso & two paired cones as the breasts & impressing a cone-pointed tool \\
TE13 & middle body, torso & negative interfaces, holes at inner elbows & rolling, joining, forming \\
TE14 & top, head & elongated semi-cylinder, right side of head & rolling, joining, forming \\
TE15 & top, head & elongated semi-cylinder, left side of head & pellet forming, flattening, joining \\
TE16 & top, head & hemisphere, headdress(?) on nape & pellet forming, flattening, joining \\
TE17 & top, head & hemisphere, headdress(?) on nape & pinching, joining \\
TE18 & top, head & flat triangular pellet & inserting, tucking-in of clay along edges \\
TE19 & top, head & Obsidian bladelets, ventral side, eyes &
\end{tabular}

\section{Discussion and conclusions}

Our review of the published literature on the manufacure of female figurines challenged implicit and simplistic assumptions, revealing at least two alternative choices (core vs. dual forming techniques). Obviously enough, we cannot expect that the two technical templates will resolve all issues. Other forming processes need to be considered along the approaches of dual and core-forming techniques.

With CT scanning, we demonstrated the actual possibility of reconstructing the modelling sequence of a prehistoric terracotta figurine with a detailed step-by-step model, without
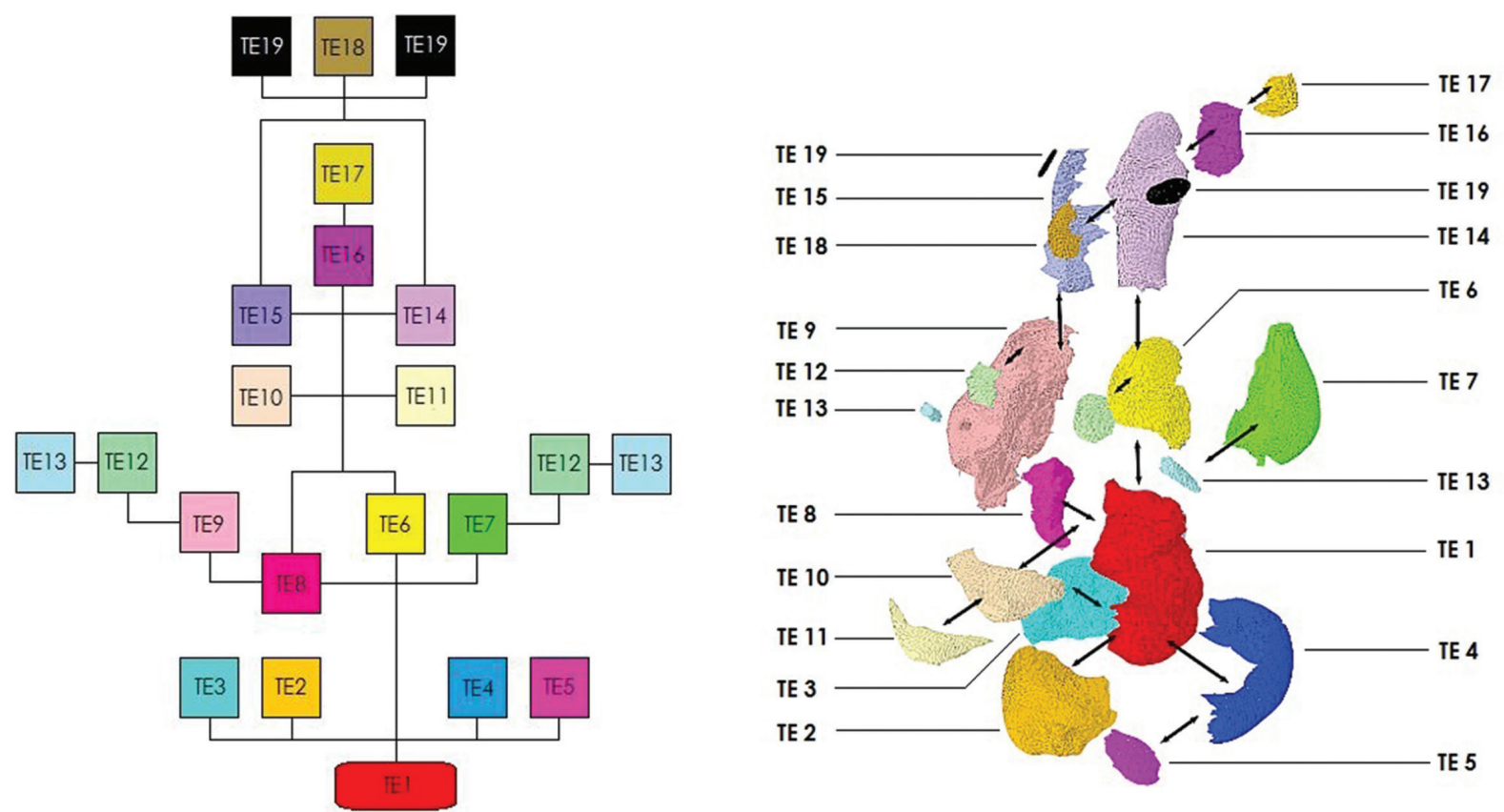

Fig. 6. Final deconstruction of the figurine in subsequent TEs, in the form of a 3D map (right) and a stratigraphic flow chart (left). Both show a fundamentally dual construction process, expressed, in particular, in the axial symmetry of the applied parts in the legs and trunk region. 
minimally damaging its integrity. The inner structure of the statuette follows, to a large extent and redundantly, an axial symmetry: in fact, parts of the legs and torso, the breasts and even the head were made by bilateral additions. Although the shape of the inflated bent legs might recall testicles, the composite structure of torso and head does not support a conceptual reference to a penis shaft, for which one would expect a much simpler construction. The hypothesis of gender ambiguity, in other words, is not supported by what we understand of the image's building process.

The inner bilateral structure of the Rome figurine matches with previous information on the châine opératoire of the Hacilar statuettes: it is certainly a variation of the dual forming approach. Its operational sequence partially replicated the strong symmetry of the figurine's painted decoration, in a fundamental (although indirect) cognitive analogy with the human body. Has this any bearing on the sacred vs. secular inspiration of the figurine? One could argue that organic analogy would be more appropriate for images of real women, rather than of deities, but this remains impossible to demonstrate.

Mina (2008, 130-131) recognized in the variability of Cretan Neolithic female figurines, possibly in their manufacturing techniques, aspects of individualism and selfprojection. The age and gender of the artists of the various categories of clay anthropomorphic figurines thus becomes a crucial issue. How far a closer focus on construction technology can lead us in this direction, it is still hard to say. In 2002, Králík et al., while studying the famous terracotta Venus of Dolní Věstonice, having measured the dermatoglyphs of a single partial fingerprint, proposed that the last individual to touch it before it dried was a young individual from 7 to 15 years old. The implications in terms of agency might have been extraordinary; but the method was questionable, and conclusions were hindered by the absence of comparanda. Advanced paleotechnological studies on the interior structure of Neolithic/Chalcolithic figurines may not straightly reveal the gender, age and agency of their makers. However, there is little doubt that further research within the figurines and a growing understanding of the chronological, spatial and cultural coordinates of the various techniques on record will help us to focus new hypotheses on the agencies and social roles in these prehistoric communities.

\section{Acknowledgements}

The authors are very grateful to Francesco Di Gennaro, Director, and to Giovanna Lombardo of the National Museum of Oriental Art "Giuseppe Tucci", Rome, for permission to study the figurine. Roberta Bollati, conservator at the Istituto Superiore per la Conservazione e il Restauro (ISCR), Rome, took care of the conservation of the object. Elisabetta Starnini and Paolo Biagi provided useful information, and Luca Bondioli (Museo Luigi Pigorini, Rome) helped in processing the CT scanning data. The text was patiently edited by Michela Spataro (British Museum) and David
Frayer (University of Kansas) and commented by Kamila Remišová Věšínová (Charles University, Prague) to whom the authors are greatly endebted.

\section{References}

ABAY, E. 2003: The Neolithic Figurines from Ulucak Höyük: Reconsideration of the Figurine Issue by Contextual Evidence. NEOLITHICS 2/03. The Newsletter of Southwest Asian Neolithic Research 2, $16-21$.

APPLBAUM, N., APPLBAUM, Y. H. 2005: The Use of Medical Computed Tomography (CT) Imaging in the Study of Ceramic and Clay Archaeological Artifacts from the Ancient Near East. In: Uda, M., Demortier, G., Nakai, I. (Eds.): X-Rays for Archaeology. Springer, Dordrecht, 231-245.

BADISHEN LANDESMUSEUM KARLSRUHE 2007 (Hrsg.): Vor 12.000 Jahren in Anatolien. Die altesten Monumente der Menschheit. Badishes Landesmuseum, Karlsruhe.

BAR-YOSEF, O. 1980: A Human Figurine from a Khiamian Site in the Lower Jordan Valley. Paleórient 6, 193-199.

BASS, G. F. 1959: Neolithic Figurines from Thespiai. Hesperia 28, 4, 344-349.

BOLGER, D. 1996: Figurines, Fertility, and the Emergence of Complex Society in Prehistoric Cyprus. Current Anthropology 37, 2, 365-373.

BOLLATI, R., CEROLI, G., HUBER, E. 2009: Quando 1'argilla non diventa ceramica: intervento pilota su manufatti iranici del III millennio a.C. In: Gualtieri, S., Fabbri, B., Bandini, G. (a cura di): Le classi ceramiche. Situazione degli studi - Atti della 10a Giornata di Archeometria della Ceramica (Roma, 5-7 aprile 2006). Edipuglia s. r. 1., Bari, 213-221.

BOLlATI, R., DI ODOARDO, B., COLADONATO, M., CONTI, L., SIDOTI, G., DI PILATO, S., LOLIVA, E., LAZZARI, A., VIDALE, M. 2012: Ceramiche protostoriche orientali. Un'esperienza didattica all'ISCR. Bollettino ICR Nuova Serie 26, 64-93.

CHAPMAN, J. 2000: Fragmentation in archaeology: People, places and broken objects in the prehistory of South Eastern Europe. Routledge, London.

CHAPMAN, J., GAYDARSKA, B. 2007: Parts and wholes. Fragmentation in prehistoric context. Oxbow books, Oxford.

CLARK, S. 2007a: The social lives of figurines: recontextualizing the Third Millennium BC terracotta figurines from Harappa, (Pakistan). A dissertation presented by Sharri Ruth Clark to The Department of Anthropology in partial fulfillment of the requirements for the degree of Doctor of Philosophy in the subject of Anthropology, Harvard University, Cambridge, Massachusetts, May 2007.

CLARK, S. R. 2007b: Bodies of evidence: The case against the "Harappan" mother goddess. In: Renfrew, C., Morley I. (Eds.): Image and imagination: A global prehistory of figurative representation. McDonald Institute for Archaeological Research, Cambridge, 227-239.

CLARK, S. R. 2009: Material Matters: Representation and Materiality of the Harappan Body. Journal of Archaeological Method and Theory 16, 231-261.

DALES, G. 1991: Some Specialized Ceramic Studies at Harappa. In: Meadow, R. H. (Ed.): Harappa Excavations 1986-1990 A Multidisciplinary Approach to Third Millennium Urbanism. Prehistory Press, Madison, 61-69.

DEBIEC, M., DZBYNSKI, A. 2006: An Early Neolithic Anthropomorphic Figurine from Zvieczica Site 3, Podkarpackie Voivodeship. Acta Archaeologica Carphatica XLI, 25-29.

DOBRES, M.-A. 2000: Technology and Social Agency: Outlining a Practice Framework for Archaeology. Oxford \& Malden (MA), Blackwell.

DOBRES, M.-A. 2009: Archaeologies of technology. Cambridge Journal of Economics 1, 1-12.

DOBRES, M.-A. ROBB, J. 2000 (Eds.): Agency in Archaeology. Routledge, New York.

GUIDOTTI, M. C., LO SCHIAVO, F., PIEROBON BENOIT, R. 2007 (Eds.): Egeo, Cipro, Siria e Mesopotamia. Dal collezionismo allo scavo archeologico. Sillabe, Livorno.

GIMBUTAS, M. 1991: The Civilization of the Goddess: The World of Old Europe. Harper, San Francisco. 
HOURMOUZIADIS, G. 1973: I anthropomorphi eidoloplastiki tis neolithikis Thessalias: Provlimata kataskevis, typologias kai ermineias. Society of Thessalian Studies, Volos.

HUGHES, S. 2011: CT Scanning in Archaeology. In: Saba, L. (Ed.): Computed Tomography - Special Applications. Accessed at the site http://www.intechopen.com/books/computed-tomography-specialapplications/ct-scanning-in-archaeology.

JARRIGE, C. 2007-2008: The figurines of the first farmers at Mehrgarh and their offshoots. Pragdhara 18, 155-156.

KNAPP, A. B., MESKELL, L. M. 1997: Bodies of evidence in prehistoric Cyprus. Cambridge Archaeological Journal 7, 2, 183-204.

KRÁLÍK, M., NOVOTNÝ, V., OLIVA, M. 2002: Fingerprint on the Venus of Dolní Vestonice I. Anthropologie (Moravské zemské muzeum, Brno, Czech Republic) 40, 2,107-113.

KREITER, A., RIEBE, D. J., PARKINSON, W. A., ÁKOS PETÕ, A., TÓTH, M., PÁNCZÉL, P., BÁNFFY, E. 2014: Unique in its chaîne opératoire, unique in its symbolism: undressing a figurine from the $6^{\text {th }}$ Millennium BC Körös culture, Hungary. Journal of Archaeological Science 44,136-147.

KUJIT, I., CHESSON, M. 2005: Lumps of Clay and Pieces of Stone. Ambiguity, Bodies and identity as Portrayed in Neolithic Figurines. In: Pollock, S., Bernbeck, R. (Eds.): Archaeologies of the Middle East: Critical Perspectives. Blackwell, Malden, M. A., 152-183.

LAMBERG-KARLOVSKY, C. C., MEADOW, R. H. 1970: A Unique Female Figurine: The Neolithic at Tepe Yahya. Archaeology 23, 1, 12-17.

LANGIN-HOOPER, S. M. 2014 (Ed.): Figuring Out the Figurines of the Ancient Near East. Occasional Papers in Coroplastic Studies, 1, Association for Coroplastic Studies.

LEMONNIER, P. 1993 (Ed.): Technological Choiches. Transformation in material cultures since the Neolithic. Routledge, London and New York.

LESURE, R. G. 2002: The Goddess Diffracted: Thinking about the Figurines of Early Villages. Current Anthropology 43, 4, 587-610.

LESURE, R. G. 2010: Interpreting Ancient Figurines: Context, Comparison, and Prehistoric Art. Cambridge University Press, Cambridge.

LOUHIVUORI, M. 2010: Understanding Neolithic Southern Levant. Case Studies of Archaeological Semiosis in Action. Åbo Akademis Förlag, Åbo Akademi University Press, Åbo.

MAKKAY, J. 1998: I primi agricoltori dell'Europa sud-orientale e il Neolitico del Bacino dei Carpazi. In: Pessina, A., Muscio, G., (Eds.) Settemila anni fa. Il primo pane. Ambienti e culture delle società neolitiche. Catalogo della mostra. Comune di Udine, Museo friulano di storia naturale, dicembre 1998-maggio 1999, 35-54.

MELLAART, J. 1967: Çatal Hüyük, A Neolithic Town in Anatolia. Thames and Hudson, London.

MELLAART, J. 1970: Excavations at Hacilar (vol.1,2). British Institute of Archaeology at Ankara, University Press, Edinburgh.

MELLAART, J. 1975: The Neolithic of the Near East. Thames and Hudson, London.

MESKELL, L. 1995: Goddesses, Gimbutas and 'New Age' archaeology. Antiquity 69, 262, 52-62.

MESKELL, L. 1998: Twin Peaks: The Archaeologies of Çatalhöyük. In: Goodison, L., Morris, C. (Eds.): Ancient Goddesses: The Myths and the Evidence. British Museum Press, London, 46-62.

MESKELL, L. 2008: The nature of the beast: curating animals and ancestors at Chatalhöyük. World Archaeology 40, 3, 373-389.

MILLER, D. 1998: Why some things matter. In: Miller, D. (Ed.): Material cultures: Why some things matter. University of Chicago Press, Chicago, $3-21$.

MINA, M. Y. 2008: Figuring out Cretan Neolithic society: anthropomorphic figurines, symbolism and gender dialectics. In: Isaakidou, V., Tomkins, P. (Eds.): Escaping the Labyrinth: The Cretan Neolithic in Context Sheffield Studies in Aegean Archaeology 8, Oxbow Books, Oxford, 115-35.
MUSCARELLA, O. W. 1971: Hacilar Ladies: Old and New. The Metropolitan Museum of Art Bulletin 30, 2, 74-79.

NAKAMURA, C. MESKELL, L. 2009: Articulate Bodies: Forms and Figures at Chatalhöyük. Journal of Archaeological Method and Theory $16,205-230$.

NANOGLOU, S. 2008: Qualities of humanness: Material aspects of Greek Neolithic anthropomorphic imagery. Journal of Material Culture 13, 3, 311-334.

NANOGLOU, S. 2010: The representation of phalli in Neolithic Thessaly, Greece. Documenta Praehistorica XXXVII, 215-225.

NISHIAKI, Y. 2007: A Unique Neolithic Female Figurine from Tell Seker al-Aheimar, Northeast Syria. Paléorient 33, 2, 117-125.

ÖZDOGAN, M. 2003: A group of Neolithic stone figurines from MezraaTeleilat. In: Özdogan, M., Hauptmann, H., Basgelen, N. (Eds.): From village to cities: early villages in the near east. Arkeoloji ve Sanat Yayinlari, Istanbul, 511-523.

PAVEL, C., SUCIU, C., CONSTANTIN, F., BUGOI, R. 2013: X-ray computed tomography investigations of Cucuteni ceramic statuettes. Documenta Praehistorica XL, 323-332.

PERLÉS, C. 2004: The Early Neolithic in Greece. The First Farming Communities in Europe. Cambridge University Press, Cambridge.

RICH, S. A. 2008: Midwifery and Neolithic Malta: interpreting and contextualizing two terracotta figurines. Omertaa, Journal of Applied Anthropology 2008, 260-268.

SAUTER, F., VARMUZA, K., WERTHER, W., STADLER, P. 2002: Studies in organic archaeometry V1: chemical analysis of organic material found in traces on an Neolithic terracotta idol statuette excavated in lower Austria. ARKIVOC, 2002, 54-60.

SKIBO, J. M., SCHIFFER, M. B. 2008: People and things: A behavioral approach to material culture. Springer, New York.

STARNINI, E. 2014: Fired clay, plastic figurines of the Körös culture from the excavations of the early neolithic sites of the Körös culture in the Körös valley, Hungary. Società per la Preistoria e Protostoria della Regione Friuli-Venezia Giulia, Quaderno 14, Edizioni Svevo, Trieste.

TINÉ, V. 2009 (Ed.): Favella. Un villaggio neolitico nella Sibaritide. Studi di Paletnologia III. Collana del Bullettino di Paletnologia Italiana, Roma. TRINGHAM, R. 2005: Weaving house life and death into place: a blueprint for a hypermedia narrative. In: Bailey, D., Whittle, A., Cummings, V. (Eds): (Un)settling the Neolithic. Oxbow books, Oxford, 98-111.

TRINGHAM, R., CONKEY, M. 1998: Rethinking figurines: a critical view from archaeology of Gimbutas, the "Goddess" and Popular Culture. In: Goodison, L., Morris, C. (Eds.): Ancient Goddesses: the Myths and the Evidence. British Museum, London, 22-45.

UCKO, P. J. 1968: Anthropomorphic Figurines of Predynastic Egypt and Neolithic Crete with Comparative Material from the Prehistoric Near East and Mainland Greece. Royal Anthropological Institute Occasional Paper No. 24., Andrew Szmidla, London.

UCKO, P. J. 1996: Mother, are you there? Cambridge Archaeological Journal 6, 2, 300-304.

VAN DER LEEUW, S. 1993: Give the potter a choice. Conceptual aspects of pottery techniques. In: Lemonnier, P. (Ed.) Technological Choices. Transformation in material Cultures since the Neolithic, Routledge, London, 238-288.

VAN DER LEEUW, S. E. 1994: Cognitive aspects of 'technique'. In Renfrew, C., Zubrow, E. B. W., (Eds.): The ancient mind. Elements of cognitive archaeology. Cambridge University Press, Cambridge, 135136.

VOIGT, M. 2007: The splendour of women: late Neolithic images from Central Anatolia. In: Renfrew, A. C., Morley, I. (Eds.): Material beginnings: a global prehistory of figurative representation. McDonald Institute Monographs,Cambridge, 151-169. 
